\title{
Foreword and Acknowledgements
}

This book is the slowly ripening fruit of my fascination with the representation of communicating gods in ancient Greek polytheism. Over more than a decade, it has benefited from the generous advice of many scholars who have commented on different versions of individual chapters at different times: Lucia Athanassaki, Ewen Bowie, Frederick Brenk, John Dillon, Nanno Marinatos, Donald Mastronarde, John Mikalson, Robert Parker, Christopher Pelling, Spyridon Rangos, Antonios Rengakos, Jörg Rüpke, and Bernd Seidensticker are those whom I still recall. I wholeheartedly thank them -and others who contributed to the book- for their time and their instructive criticism.

Two scholars in particular facilitated the publication of this book. Georgia Petridou, the (initially anonymous) reviewer, put at my disposal her profound expertise and even greater generosity in sponsoring an approach that responded critically to -rather than continuing- her own contributions to the field. Even more, I must thank Anton Bierl, editor of $M E P$, who stood by the book unreservedly, devoted much time to scholarly and editorial discussions, was always reliable, efficient, available and quick in his judicious responses, in a word, a $\pi \alpha-$

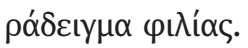

As for the more technical aspects of the completed version of the book, Katharina Legutke, acquisitions editor of classical studies at DeGruyter, as well as Anne Hiller and Ulla Schmidt, both responsible for the production process, saw the text through the press in a professional, unbureaucratic, and always good-humored mood. In particular, Ulla Schmidt was extremely generous with her time and her acumen, in ensuring the swift and accurate realization of hundreds of corrections in the numerous proofs. Besides, Brian McNeil checked the English (and thereby also its contents). Brian's astonishing efficiency in reading through large amounts of texts with incredible speed and still painstaking attention to detail is only matched by his even greater kindness of reading similar versions again and again. Still, in terms of patience no one could possibly match my wife, Elena, who for yet another decade bore my quirks and long absences in Athens with her characteristic stoic and caring resilience.

I have tried to include relevant bibliography until 2020, with a deliberate emphasis on more recent publications. But while I thereby try to be as up-to-date and balanced as possible, I refrain from heaping up bibliography for the bibliography's sake. Given that the book covers a millennium of textual production in more than a dozen genres, no one will expect to find a full discussion of all relevant approaches that scholars in the past have taken to individual issues. Instead, I will give precedence to my own argument and respond primarily to 
those approaches which either reinforce or oppose it. Although I have tried hard to read and sift most relevant bibliography, I am aware that, inevitably, I will have missed some important contributions. Still, despite the truism that the bibliography is enormous, let it be said that omission does not automatically imply ignorance on my part. Relevance and focus remain debatable matters, especially when dealing with such an enormous bulk of textual material.

My translations are mostly adaptations from existing translations or new translations from scratch. Preferably, due to availability, I rely on the most recent Loeb translations. As for transcriptions of proper names, I prioritize lucidity over consistency. The same holds true of my abbreviations of ancient sources. Most of them are based on the 9th edition of Liddell \& Scott (1940), while some follow the fourth edition of the Oxford Classical Dictionary (2012); others are my own. I generally adhere to Latin or English, when referring to work titles, but in the case of fragments, I normally offer a transcription of the Greek titles (without diacritics) because such a procedure facilitates identification better than translating the Greek title into Latin or English.

As for the numbering of fragments, in those cases in which I follow standard editions such as PCG and $\operatorname{TrGF}$, I do not mark the source edition specifically. For reasons of convenience (although not systematically), I sometimes refer the reader to the Loeb translations of dramatic fragments. Here, the introduction to the relevant plays is often very useful to get a quick idea of the highly conjectural contexts or contents. Where I quote fragments according to less standardized collections, I mark the source by the surname of the editor, whose edition I use.

Like its three precursors, this book was written on the second floor of the Davis Wing of the American School of Classical Studies at Athens (= ASCSA), in the Byzantine Room of the British School at Athens (= BSA), and in the beautiful gardens that surround them. It is with profound and long-overdue gratitude that I dedicate it to these timeless havens of scholarly contemplation. 